A

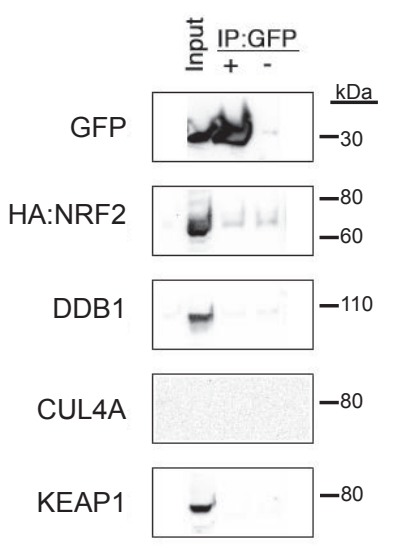

B

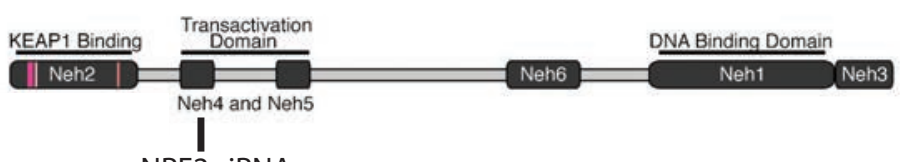

NRF2 SiRNA

(Invitrogen s9492)

$\alpha$ NRF2

(SantaCruz H-300)

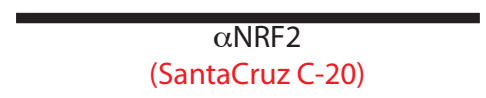

C

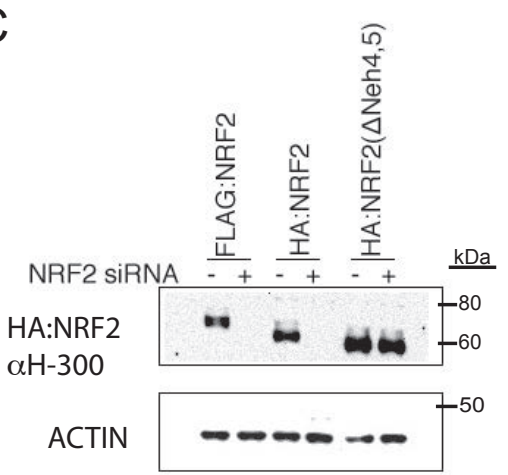

D

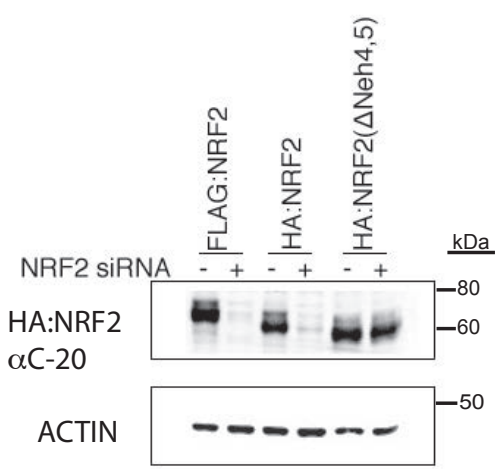

\title{
Lo and Curran
}

Figure S3 